\title{
Teaching Practices in Secondary Schools' Online Learning during Pandemic Times
}

\author{
Giselle Ann Alcoran-Alvarez ${ }^{*} \quad$ Noel N. Pit ${ }^{2} \quad$ Margie D. Amida ${ }^{3} \quad$ Arthur D. Rosalem $^{3}$ \\ Kenneth Paul C. Duran ${ }^{3} \quad$ Shiela Mae V. Galon ${ }^{3} \quad$ Erven K. Noay ${ }^{3}$ Maria Milagros C. Velez ${ }^{3}$ \\ 1.Physics and Geology Department, Negros Oriental State University, Kagawasan Avenue, \\ 6200 Dumaguete City, Negros Oriental, Philippines \\ 2.Lourdes College, Capistrano St., 9000 Cagayan de Oro, Misamis Oriental, Philippines \\ 3.Graduate School, St. Paul University Dumaguete, 6200 Dumaguete City, \\ Negros Oriental, Philippines
}

\begin{abstract}
The COVID 19 pandemic challenges the economy as well as education. Teachers have to be creative and innovative in their strategies as they migrate from face-to-face to online. Practices need to be adaptive to a situation where the students become anxious and stressful because of the sudden shift. This study investigated practices in teaching online classes. Descriptive and inferential statistics like MANOVA, ANOVA and LSD Post Hoc Test were used to analyze the responses from 159 respondents. Results showed that teachers used emotionally-related teaching practices such as mindfulness of the learners' feelings and responses, positive attitude towards the learners, availability of the teachers when students needed help, and provision of avenues for student consultation. These teaching practices significantly differ in terms of the school. Practices in the use of interactive tools, games, physical exercises at certain times during online learning, cracking jokes and using humor during online classes had also significantly vary for each school. Teaching practices during the pandemic times solely depend on the capability of the school, teachers' knowledge on technology, and maturity and experiences of teachers.
\end{abstract}

Keywords: Online Learning, Teaching Practices, Pandemic, Secondary Schools

DOI: $10.7176 / \mathrm{JEP} / 12-36-03$

Publication date: December $31^{\text {st }} 2021$

\section{Introduction}

The COVID 19 pandemic challenges not only the economy but the education as well. Teachers have to be creative and innovative in their strategies as they migrate from face-to-face to the online classroom. Practices need to be adaptive to a situation where the students become anxious and stressful because of the sudden change in the classroom environment. In the US, the Department of Education through its Office of the Civil Rights is urging educators and leaders of the schools to dedicate their talents and resources to cater to the needs of the students who were affected by the effects of pandemic (USDE-OCR, 2021). Similar report said that the abrupt shift to learning was observed to affect the K-12 in terms of mental health challenges as well as their well-being, technological barriers, heightened risk for anxiety and stress, and loss of access to student organizations and peers that support and affirm them, teachers, and school staff. On a positive note, students and teachers from the 13 countries in Europe find it easier to adapt to the current change. However, looking at the effectiveness of online learning, similar study found out that it is much lower compared to face-to-face (Tartavulea, Albu, Dieaconescu, \& Petre, 2020). However, Amiel and Vicent (2021) reported that European students felt the impact of the pandemic in their education, mental health, and socioeconomic status (Euronews, 2021). The report cited economic hardship, isolation, educational concerns, and uncertainty are contributory factors of mental health issues among young people. The Asia-Pacific region is not spared of the tremendous effect of the pandemic with closures of schools and digital divides. Teachers have to adapt to new platforms and methods to ensure students' continuous learning (Kang \& Seo, 2021; Moorhouse \& Wong, 2021; Zhang, Yan \& Wang, 2021). A year after the pandemic, students were found to develop anxiety and stress. The perceived stress of the students was strongly related to their anxiety and depression which means that those who have higher levels of stress will have chances to develop depression and anxiety (Marcén-Román et al., 2021). Stress among Filipino students can be indicated by being temperamental and unable to sleep during the night. However, in order for them to cope with stress, they resorted to prayer and the use of computer (Rotas \& Cahapay, 2021). Anderson (2020) pointed out the necessity of positive and healthy dispositions during this time of crisis because it allows learning to happen. Learner-centered teaching methods and counseling using the online platform are effective ways in the academic achievement of the students (Toquero, 2020). Redinger, Cornia, and Albert (2020), emphasized the need to support the mental health of the trainees as they are also vulnerable to it. These trainees need to be provided with resources related to their well-being and an environment that provides safety, genuineness, and welcome. Teachers can help students cope with stress by being cool, establishing a regular routine, and discussing COVID-19 with them (CDC, 2020b). With these background, teachers have significant roles to play in this time of pandemic. And one of its role is to think of strategies that will help the students minimize stress and anxiety inside and outside the virtual classrooms. It is then imperative 
to understand the practices of teachers in this part of the Philippines and how it varies given their sociodemographics. Hence, this study.

\section{Statement of the Problem}

This study looked into the teaching practices in online learning among the secondary school teachers during pandemic times. Specifically, this study aimed to answer the following questions: 1) What are the demographic characteristics of the respondents? 2) What is the extent of teaching practices in online learning when grouped according to a) intellectually-related, b) physically-related, and c) emotionally-related practices? and 3) Do the teaching practices significantly differ according to each of the following a) school, b) age, c) teaching experience, and d) educational qualification?

\section{Framework of the Study}

This research is anchored on the Cognitive-Mediational Theory (Lazarus, 1991), Transactional Theory of Stress and Coping (Lazarus, 1966; Lazarus \& Folkman, 1991), and Theory of Stress and Stimulus (Holmes \& Rahe, 1967). Cognitive-Mediational Theory (Lazarus, 1991) argued that emotions are the product of how persons appraise the stimuli which are of two major types: primary appraisal and secondary. The primary appraisal determines the meaning and significance of an event and describes how much is the threat or stressor. The secondary appraisal assesses the person's ability to cope with the results of an event. In this study, the online learning experiences of the students are considered as the stimuli. Resulting from their appraisal of these stimuli caused them anxiety and stress. Although the online learning can be meaningful and significant in the academic life of the students, however, there is also a corresponding threat or stressor as these stimuli are totally a different experience. The students are seemed to lack the ability to cope with demands of online learning. This is the reason why teachers should become innovative enough in their practices in the virtual classroom to address these emotions of the students and to help them to be comfortable with the new environment. On the other hand, Transactional Theory of Stress and Coping (Lazarus, 1966; Lazarus \& Folkman, 1984) claimed that stress is a result of the transaction between two persons and their surroundings. Transaction, in this study, happened between the students and the teacher including the online classroom environment. This transaction can be stressful among the students as well as the teachers as nobody is prepared for this kind of situation especially with technology and accessibility of the online platforms (Elsalem et al., 2020; Fernández-Batanero et al., 2021). As demanded from the work of a teacher, it is just necessary to innovate teaching strategies and activities to ease up the feelings and emotions of the students for learning to take place in times of pandemic. Lastly, the Theory of Stress as Stimulus (Holmes \& Rahe, 1967) assumed that changes can be stressful in itself; the degree of adjustments is similar to any events in life; and adjustment threshold is common which illness will result beyond this threshold. Students' lives are inherently stressful because of the many demands of the school and the other contributory factors of this stress. In times of pandemic, the online learning experience is a change that occurs in students' lives which can be equally stressful for them. They needed to adjust to this kind of environment. And this adjustment is similar to the pains of other adjustments in life. Adjustments depend on the students' threshold to bear their experience of the situation. However, many of these students felt anxious and stressed as they try to adjust to this environment. Thus, it is necessary for the teachers to help them cope with the shift by employing activities and strategies to facilitate the students in transitioning to this new normal way of learning.

\section{Methodology}

This study determined the teaching practices in online classes during pandemic. A total of 159 teachers from the 7 secondary schools in Dumaguete City, Negros Oriental, Philippines responded to the survey. Data were collected using a 20-item, researcher-made survey questionnaire. Purposive sampling and snowball technique were employed due to the Modified Enhanced Community Quarantine (MECQ) restrictions in the area. Onwuegbuzie and Collins (2007) proposed these combined sampling methods when respondents are difficult to reach. The following criteria were used to obtain the samples: 1) Teachers are handling online classes in the secondary schools in Dumaguete City; 2) They must be 20 years old or more during the time of their teaching; and 3) They must be recommended by their principal or school heads to join the survey. Since the survey was conducted using Google Forms because of the difficulty of mobility, the number of samples depend on those who responded to the online survey. The survey instrument was subjected to a dry-run to establish its reliability and validity. This instrument has an internal consistency of 0.862 Cronbach's Alpha value which is considered good (Aron, Coups \& Aron, 2013). Permission from school heads was sought. Upon their approval, the survey was conducted from the July 1 to 15,2021 . Data were collated and analyzed using descriptive and inferential statistics. SPSS 27 was used to determine the frequency, percentage, mean (M), standard deviation (SD), MANOVA, ANOVA and LSD post hoc test. Less than 3 standard deviation was interpreted as homogeneous levels of response while standard deviation greater than or equal to 3 was heterogeneous (Aiken \& Susane, 2001). The scale and means were described as follows: 5 (4.20-5.00) All the Time/Daily (ATT); 4 (3.40-4.19) Most of The Time (MOTT) (Thrice a Week); 3 
(2.60-3.39) Sometimes (SO) (Twice a Week); 2 (1.80-2.59) Seldom(SE) (Once a Week), and 1 (1.00-1.79) Not At All (Never Done At All).

\section{Results}

\subsection{Demographic Characteristics}

Table 1 shows the demographics in terms of: specific school, age, teaching experience, and educational qualification. Results revealed that $25.16 \%$ belonged to School A and another $25.16 \%$ belonged to School C; $17.61 \%$ are in the age bracket of 40-44 years old; $20.75 \%$ have 1-3 years of teaching experience; and 76.1\% are Bachelor's degree holder. Data show that majority of the respondents are teaching in the two schools. In terms of age, though the highest in the age groups is 40-44 years old, however, it can also be gleaned in the table that there were closer age groups with almost similar percentage such as the age group 35-39 and 50 to 54. It means that the respondents are closely related in terms of ages. The respondents are new teachers with an experience of 1 to 3 years.

\subsection{Extent of Teaching Practices}

Table 2 presents the teaching practices as: intellectually-related, physically-related, and emotionally-related practices. Results revealed an overall mean of $4.07(S D=0.41)$ interpreted as most of the time. The mean of each group of is as follow: intellectually-related group $(M=3.85, S D=0.51)$, physically-related group $(M=3.94$, $S D=0.56)$, and emotionally-related group $(M=4.29, S D$ 0.45). The overall mean suggests that respondents are employing intellectually, physically, and emotionally-related practices most of the time. Moreover, emotionallyrelated group has the highest mean and physically-related group has the lowest mean. These emotionally-related practices are mindful of the learner's feelings and responses, manifests a positive attitude, exhibits a happy disposition at all times, listens with a heart(sincerely), generous with praise; cautious with sarcasm, never ignore an opportunity to help, gentle in giving reminders/corrections.

\section{Table 1: Demographic Characteristics}

\begin{tabular}{|c|c|c|c|c|}
\hline Categories & $\begin{array}{c}\text { Frequency } \\
\mathbf{N}=159\end{array}$ & $\%$ & Mean & SD \\
\hline \multicolumn{5}{|l|}{ School } \\
\hline $\mathrm{A}$ & 40 & 25.16 & 4.05 & 0.41 \\
\hline $\mathrm{B}$ & 12 & 7.55 & 3.87 & 0.37 \\
\hline $\mathrm{C}$ & 40 & 25.16 & 4.10 & 0.39 \\
\hline $\mathrm{D}$ & 35 & 22.01 & 4.19 & 0.44 \\
\hline $\mathrm{E}$ & 14 & 8.81 & 4.07 & 0.34 \\
\hline $\mathrm{F}$ & 11 & 6.92 & 4.04 & 0.47 \\
\hline G & 7 & 4.40 & 3.86 & 0.48 \\
\hline \multicolumn{5}{|l|}{ Age } \\
\hline$(20-24)$ yrs. & 9 & 5.66 & 4.14 & 0.49 \\
\hline$(25-30)$ yrs. & 21 & 13.21 & 4.01 & 0.46 \\
\hline$(30-34)$ yrs. & 21 & 13.21 & 3.93 & 0.33 \\
\hline$(35-39)$ yrs. & 25 & 15.72 & 4.07 & 0.36 \\
\hline$(40-44)$ yrs. & 28 & 17.61 & 4.04 & 0.41 \\
\hline$(45-49)$ yrs. & 17 & 10.69 & 4.25 & 0.40 \\
\hline$(50-54)$ yrs. & 23 & 14.47 & 4.08 & 0.45 \\
\hline$(55-59)$ yrs. & 15 & 9.43 & 4.15 & 0.43 \\
\hline \multicolumn{5}{|l|}{ Teaching Experience } \\
\hline$(1-3)$ yrs. & 33 & 20.75 & 4.13 & 0.42 \\
\hline (4-6) yrs. & 27 & 16.98 & 4.02 & 0.44 \\
\hline (7-9) yrs. & 30 & 18.87 & 3.97 & 0.39 \\
\hline$(10-12)$ yrs. & 12 & 7.55 & 4.06 & 0.37 \\
\hline$(13-15)$ yrs. & 13 & 8.18 & 4.12 & 0.32 \\
\hline (16-18) yrs. & 12 & 7.55 & 4.07 & 0.31 \\
\hline (19-above) yrs. & 32 & 20.13 & 4.13 & 0.48 \\
\hline \multicolumn{5}{|l|}{ Educational Qualification } \\
\hline Bachelor & 121 & 76.1 & 4.08 & 0.41 \\
\hline Masteral & 33 & 20.8 & 4.07 & 0.44 \\
\hline Doctorate & 5 & 3.1 & 3.84 & 0.21 \\
\hline
\end{tabular}

It emphasizes the importance of the learners' feelings during pandemic which reaffirms the school's role as an excellent place to assist students' emotional well-being especially positive and healthy dispositions (Anderson, 2020). It is therefore imperative for educators to assist students by involving guidance counselors the students are getting bored, anxious, and suffering from mood swings (Irawan, Dwisona, \& Lestari, 2020). On the other hand, 
physically-related teaching practices such available at all times and encourages learners to sleep eight hours a day were used at all times. The presence of the teachers needs to be considered as it improves the online learning experience especially in opening avenues for teacher-student communication (Blaine, 2019). This reiterates the need to support mental health like the need to provide resources for the well-being of the learners with an environment that provides safety, genuineness, and welcome (Redinger, Cornia, \& Albert, 2020). Similarly, there were also practices to minimize intellectual stress that were done most of the times. These practices include: provide student consultation and organizes schedule. Creating a venue for the students to consult with the teacher enables to bridge communication gap between the teacher and student. The practice of keeping in touch or communicating is necessary. Some schools have developed another way of addressing the difficulties of students in their academic endeavors using application for online consultation (Ayo et al., 2020).

Table 2. Teaching Practices

\begin{tabular}{|c|c|c|c|}
\hline Practices & Mean & SD & Verbal Description \\
\hline \multicolumn{4}{|l|}{ Intellectual } \\
\hline organizes schedule & 4.23 & 0.86 & ATT \\
\hline plays sweet music & 3.50 & 1.07 & MOTT \\
\hline never overschedule activities for the day & 3.36 & 1.08 & $\mathrm{SO}$ \\
\hline employs interactive learning tool e.g. games & 3.69 & 0.94 & MOTT \\
\hline provides student consultation & 4.37 & 0.67 & ATT \\
\hline limits giving of homeworks/assignments & 3.97 & 0.89 & MOTT \\
\hline Mean and Standard Deviation & 3.85 & 0.51 & MOTT \\
\hline \multicolumn{4}{|l|}{ Physical } \\
\hline have quite moments/reflect & 3.77 & 0.90 & MOTT \\
\hline teaches stress reduction techniques e.g. breathe in and breathe out & 3.77 & 0.95 & MOTT \\
\hline encourage physical exercise at certain times & 3.43 & 0.96 & MOTT \\
\hline available at all times & 4.53 & 0.63 & ATT \\
\hline encourages learners to sleep eight hours a day & 4.20 & 0.88 & ATT \\
\hline Mean and Standard Deviation & 3.94 & 0.56 & MOTT \\
\hline \multicolumn{4}{|l|}{ Emotional } \\
\hline manifests a positive attitude & 4.61 & 0.53 & ATT \\
\hline creates a coping toolbox/release feeling is a group chat box & 3.35 & 1.27 & $\mathrm{SO}$ \\
\hline gentle in giving reminders/corrections & 4.37 & 0.72 & ATT \\
\hline listens with a heart(sincerely) & 4.47 & 0.64 & ATT \\
\hline generous with praise; cautious with sarcasm & 4.43 & 0.64 & ATT \\
\hline mindful of learner's feelings and responses & 4.65 & 0.54 & ATT \\
\hline cracks jokes; uses humor & 3.82 & 0.89 & MOTT \\
\hline never ignore an opportunity to help & 4.42 & 0.65 & ATT \\
\hline exhibits a happy disposition at all times & 4.48 & 0.61 & ATT \\
\hline Mean and Standard Deviation & 4.29 & 0.45 & ATT \\
\hline Grand Mean and Standard Deviation & 4.07 & 0.41 & MOTT \\
\hline
\end{tabular}

Figure 1 presents the frequency of occurrence of each of the teaching practices in the following group emotionally-related (emotional), physically-related (physical), and intellectually-related (intellectual). In relation to Table 2 above, it can be further gleaned that the figure is mostly dominated by the sky blue bars that represent the statements that occurred all of the time as compared to the lavender, green, red, and navy blue bars. This is followed by the lavender bars that represent most of the time. It is in the emotionally-related statements that most of the longest sky blue bars can be observed. It reinforces the results in Table 2 that the teaching practices of the respondents are within the emotionally-related group.

\subsection{Significant Difference in the Teaching Practices}

MANOVA results revealed a significant difference in the teaching practices based on school with $F(120$, $828)=1.251, \mathrm{p}<0.05$; Pillial's Trace $=0.921$, partial $\eta^{2}=0.153$ ). Since the null hypothesis is rejected using the Pillial's Trace, the ANOVAs were performed. Despite the Levene's tests showing non-homogeneity of variance in five dependent variables, the analysis proceeds with getting the ANOVAs because the standard deviation of all dependent variables are less than 3 and the sample sizes are unequal. 


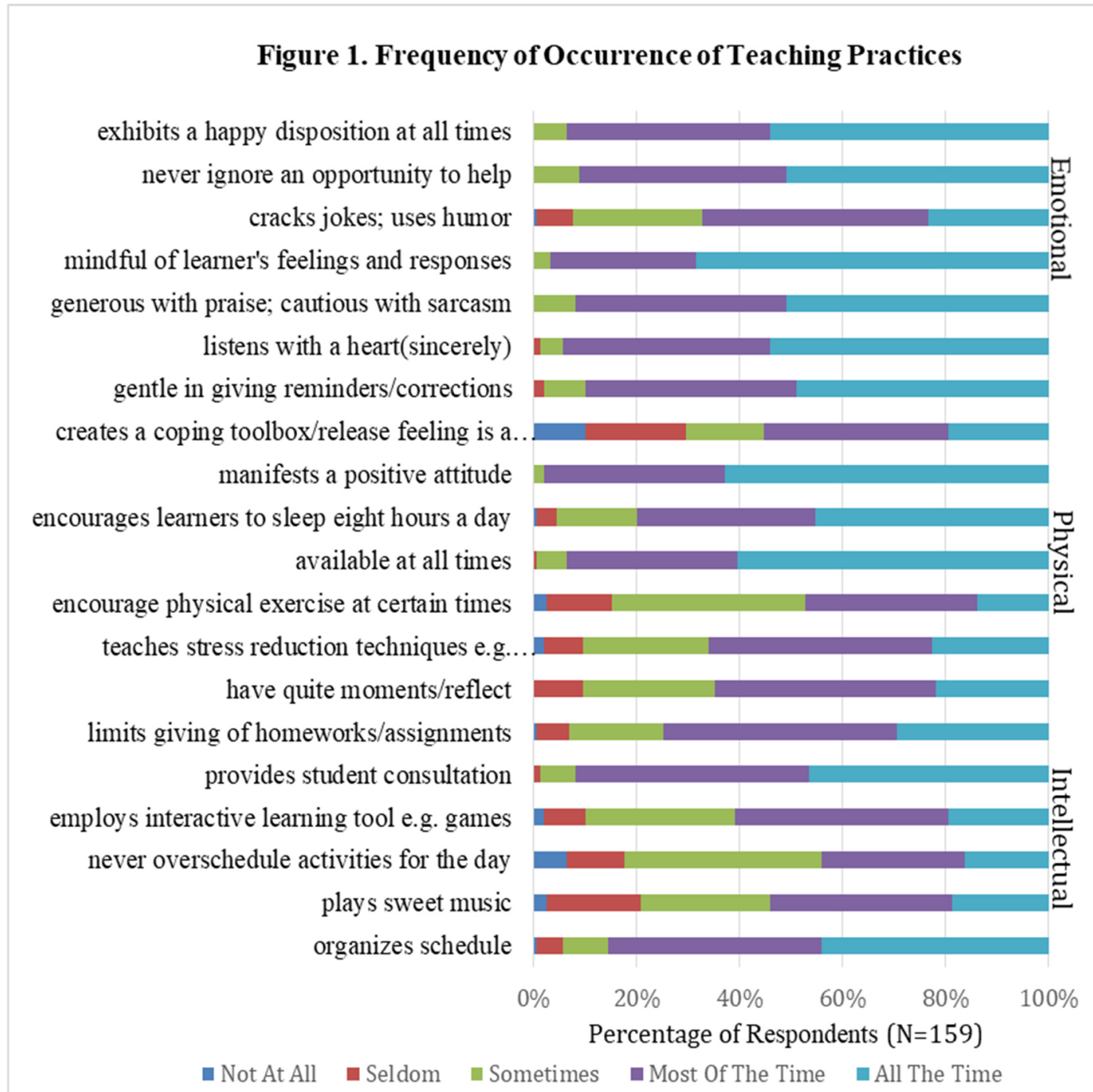

Table 3 presents the separate ANOVAs of the twenty dependent variables based on school where I1-I6 are the intellectual, P1-P5 are the physical and E1-E9 are the emotional teaching practices. In Figure 1, these statements can be viewed from bottom to top of the chart. Results showed the following $F$ ratios for each group of dependent variables: intellectually-related group $(6,2.044), \mathrm{p}<0.05$; physically-related group $(6,2.194) \mathrm{p}<0.05$; and emotionally-related group $(6,1.904), \mathrm{p}<0.05$. The findings confirm that there is a significant difference according to school in terms of the following practices in each group such as the employing of interactive tool which includes games to minimize stress, encouraging physical exercises at certain times during online learning, and cracking jokes and using humor.

Subsequent multiple comparisons post hoc Fisher's LSD tests are presented in Tables 4, 5, 6, 7, and 8. In Table 4, it is presented that there is a significant difference in the column labeled Mean difference (I-J). The mean difference values accompanied by asterisks indicate that the teachers at school $\mathrm{D}$ use of interactive tools like games is significantly higher than schools A, B and E at the 0.05 level of significance. This implies the type of leadership exhibited heightened with the provisions of computers with free monthly internet connectivity by private donors. 
Table 3. ANOVAs of the Dependent Variables as a Function of School

\begin{tabular}{ccccccc}
$\begin{array}{l}\text { Dependent } \\
\text { Variable }\end{array}$ & $\begin{array}{l}\text { Type III Sum of } \\
\text { Squares }\end{array}$ & df & Mean Square & F & Sig. & $\eta^{2}$ \\
\hline I1 & 6.568 & 6 & 1.095 & 1.515 & 0.177 & 0.056 \\
I2 & 8.282 & 6 & 1.38 & 1.21 & 0.304 & 0.046 \\
I3 & 11.401 & 6 & 1.9 & 1.665 & 0.133 & 0.062 \\
I4 & 12.267 & 6 & 2.044 & 2.428 & $0.029^{*}$ & 0.087 \\
I5 & 2.495 & 6 & 0.416 & 0.921 & 0.481 & 0.035 \\
I6 & 6.206 & 6 & 1.034 & 1.325 & 0.249 & 0.05 \\
P1 & 2.755 & 6 & 0.459 & 0.558 & 0.763 & 0.022 \\
P2 & 4.356 & 6 & 0.726 & 0.803 & 0.569 & 0.031 \\
P3 & 13.163 & 6 & 2.194 & 2.491 & $0.025^{*}$ & 0.09 \\
P4 & 2.494 & 6 & 0.416 & 1.035 & 0.405 & 0.039 \\
P5 & 1.62 & 6 & 0.27 & 0.336 & 0.917 & 0.013 \\
E1 & 1.967 & 6 & 0.328 & 1.191 & 0.314 & 0.045 \\
E2 & 8.702 & 6 & 1.45 & 0.89 & 0.504 & 0.034 \\
E3 & 1.223 & 6 & 0.204 & 0.388 & 0.886 & 0.015 \\
E4 & 1.809 & 6 & 0.302 & 0.718 & 0.635 & 0.028 \\
E5 & 2.805 & 6 & 0.468 & 1.144 & 0.340 & 0.043 \\
E6 & 0.93 & 6 & 0.155 & 0.523 & 0.790 & 0.02 \\
E7 & 11.424 & 6 & 1.904 & 2.547 & $0.022^{*}$ & 0.091 \\
E8 & 4.908 & 6 & 0.818 & 2.01 & 0.068 & 0.074 \\
E9 & 3.808 & 6 & 0.635 & 1.727 & 0.118 & 0.064 \\
\hline
\end{tabular}

*Significant at 0.05 level

Moreover, the principal of School D continuously seeks strong linkages. Furthermore, as a performing school, School D garnered several awards in the division city and regional levels. The focus for good performance has in turn cascaded to students and stakeholders thereby motivating students to hone on their technology skills. Furthermore, results showed that school B has significantly lower mean in the use of interactive tool compared to School $\mathrm{G}$ with mean difference of $-0.8929, \mathrm{p}=0.043$. The constant change of school administrator, and the transfer of teachers of School B to the city proper affected the delivery of student services. The leadership style of principals has been very significant in motivating their respective teachers. As it is, the leadership style of academic leaders which allows teachers to participate in planning and decision-making have significant impacts that made teachers motivated and satisfied as they took part of in planning and development (Cansoy, 2019). Quality education comes with democratic leadership, open communication of stakeholders and well-planned curriculum. A supported teachers' performance-oriented learning can also become effective and efficient in making students' progress and achievement (Zhang, Wong, \& Wang, 2021).

The results in Table 5 discloses that the teachers in school $\mathrm{G}$ (remotest and farthest) level of student encouragement to exercise at certain times is significantly lower from schools A, C and D. The culture of letting children indulge in physical exercises even on online classes has not been fully demonstrated in School G due to the type of leadership and the teachers are aging over 50 and above. Table 6 reveals the teachers in school D use of jokes and humor during online class level which is significantly higher than schools $\mathrm{B}, \mathrm{C}$ and $\mathrm{F}$. This again underscores the fact that the leader of School D deals with the faculty in a jovial and humorous manner.

Table 4. LSD Post Hoc Tests Showing Multiple Comparisons of Schools and Teachers' Use of Interactive Learning Tool

\begin{tabular}{ccccc} 
(I) School & (J) School & Mean Difference (I-J) & Std. Error & Sig. \\
\hline School D & School A & 0.586 & 0.212 & $0.007^{*}$ \\
& School B & 0.836 & 0.307 & $0.007^{*}$ \\
& School C & 0.386 & 0.212 & 0.071 \\
& School E & 0.729 & 0.290 & $0.013^{*}$ \\
& School F & 0.449 & 0.317 & 0.159 \\
& School G & -0.057 & 0.380 & 0.881 \\
\hline
\end{tabular}

*Significant at 0.05 level 
Table 5. LSD Post Hoc Tests Showing Multiple Comparisons of Schools and Teachers' Encouragement to Exercise at Certain Times

(I) School (J) School Mean Difference (I-J)

Std. Error

Sig.

\begin{tabular}{ccccc} 
School G & School A & -1.121 & 0.385 & $0.004^{*}$ \\
& School B & -0.571 & 0.446 & 0.202 \\
& School C & -1.221 & 0.385 & $0.002^{*}$ \\
& School D & -1.114 & 0.389 & $0.005^{*}$ \\
& School E & -0.857 & 0.434 & 0.050 \\
& School F & -0.753 & 0.454 & 0.099 \\
\hline
\end{tabular}

*Significant at 0.05 level

Roy's Largest Root statistics revealed a significant difference in teaching practices based on age with $\mathrm{F}(20$, $138)=2.390, p=0.002$; Roy's Largest Root $=0.346$, partial $\eta^{2}=0.257$. Follow up ANOVAs showed that among all twenty dependent variables, there is a significant difference on teachers'

Table 6. LSD Post Hoc Tests Showing Multiple Comparisons of Schools and Teachers' Cracking of Jokes and Humor

\begin{tabular}{ccccc}
\multicolumn{1}{c}{ (I) School } & (J) School & Mean Difference (I-J) & Std. Error & Sig. \\
\hline \multirow{3}{*}{ School D } & School A & 0.061 & & \\
& School B & 0.836 & 0.200 & 0.762 \\
& School C & 0.411 & 0.289 & $0.004^{*}$ \\
& School E & 0.157 & 0.200 & $0.042^{*}$ \\
& School F & 0.722 & 0.273 & 0.566 \\
& School G & 0.371 & 0.299 & $0.017^{*}$ \\
& & & 0.358 & 0.301 \\
\hline
\end{tabular}

*Significant at 0.05 level

manifestation of positive attitude based on age with $F(7,0.571)=2.167, p=0.040$ and partial $\eta^{2}=0.091$ only. As shown in Table 7, subsequent multiple comparisons post hoc LSD tests disclosed that 25-29 years old teacher's level positive attitude manifestation during online classes is significantly higher than 20-24 years old and 30-44 years old. This shows that the new teachers are still struggling to adjust in the school environment while those from 25-29-age group have already gained experience in dealing with diverse student population thereby enabling them to localize lessons while injecting humor and wit to motivate students. Furthermore, what is noteworthy is that after the age bracket of 30-44 years old, there is a decline in the positive attitude heightened with the pandemic scenario. Generally, as people aged, health and financial issues confront them and color their life's vision thereby constraining the degree of positive outlook compared to the time when they were 25-29 years old. Howell (2020) asserted that young teachers struggle in their first few years of teaching. Their focus is on the delivery of instructions. However, the school can help new and young teachers improve, develop and hone their skills to keep them in the teaching profession as well as increase student learning and achievement. Mentoring programs, academic chat and sharing of teaching experiences among colleagues particularly with the experienced one can help young teachers cope in the struggles they encounter daily. According to Kini \& Podolsky (2019), as the teacher's teaching experience increases, teacher effectiveness correspondingly increases. He added that experiences teachers gain lead them to do better and arouses learners' interest, motivation, engagement and student success. Chiu (2019) perceived that experienced teachers have difficulties in migrating and coping with the new trends in Internet technologies. However, it was found out that there is a dramatic increase of older people learning and using new technologies. This goes to show that educators are always on-the-go and are willing to be taught and trained for the betterment of their respective learners. This was supported by Creech (2019) as he believed that, despite the barriers the teachers have faced on the current changes in education, experienced teachers need to adjust and uphold high professional standard to the new norm in teaching. MANOVA results revealed a significant difference in teaching practices to minimize stress based on teaching experience, $F(20,138)=2.098, p<.05$; Roy's Largest Root $=0.304$, partial $\eta^{2}=0.233$. Follow up ANOVAs showed that there is a significant difference on the giving of assignments and homework based on teaching experience with $\mathrm{F}(6,2.271)=3.104, \mathrm{p}=0.007$ and partial $\eta^{2}=0.109$

Multiple comparisons post hoc LSD tests as revealed in Table 8 shows that the limit to the assignments and homework given by teachers is significantly lower among 16-18-year-experience teachers than the rest of the teachers except for the 10-12-year-experience teachers. 
Table 7. LSD Post Hoc Tests Showing Multiple Comparisons of Age and Teachers' Positive Attitude

\begin{tabular}{clccc} 
(I) Age & $(\mathrm{J})$ Age & Mean Difference (I-J) & Std. Error & Sig. \\
\hline (25-29) yrs. old & $(20-24)$ yrs. & 0.460 & 0.205 & $0.026^{*}$ \\
& $(30-34)$ yrs. & 0.571 & 0.158 & $0.000^{*}$ \\
& $(35-39)$ yrs. & 0.305 & 0.152 & $0.047^{*}$ \\
& $(40-44)$ yrs. & 0.333 & 0.148 & $0.026^{*}$ \\
& $(45-49)$ yrs. & 0.317 & 0.168 & 0.061 \\
& $50-54)$ yrs. & 0.253 & 0.155 & 0.105 \\
& $(55-59)$ yrs. & 0.171 & 0.174 & 0.325 \\
\hline
\end{tabular}

*Significant at 0.05 level

Table 8. LSD Post Hoc Tests Showing Multiple Comparisons of Teaching Experience and Teacher's Limit in Giving Homework and Assignments

(I) Experience

(16-18) yrs.

\section{(J) Experience}

$(1-3)$ yrs.

(4-6) yrs.

(7-9) yrs.

(10-12) yrs.

(13-15) yrs.

(19-above) yrs.
Mean Difference (I-J)

$-0.826$

$-0.954$

$-0.950$

$-0.667$

$-0.994$

$-1.198$

\begin{tabular}{cc} 
Std. Error & Sig. \\
\hline 0.288 & $0.005^{*}$ \\
0.297 & $0.002^{*}$ \\
0.292 & $0.001^{*}$ \\
0.349 & 0.058 \\
0.342 & $0.004^{*}$ \\
0.290 & $0.000^{*}$
\end{tabular}

*Significant at 0.05 level

This could be attributed to the fact that those with teaching experience from 16-18 years where schooled in the traditional face to face manner where assignment was part of mental discipline and training to gain cognitive knowledge. It should be noted that during the time of DepEd Secretary Armin Luistro, elementary teachers were already mandated to limit the quantity of assignments to provide pupils more time to relax and rest together with their family (Luistro, 2010). More so, the current DepEd Secretary Leonor Briones also expressed her support to include the entire K-12 learners to the proposed no homework policy on weekends to provide balance between schooling and life (Aguilar, 2019). Also, since these experienced teachers have difficulty using the learning management system has hindered them from finishing their lessons have instead given these unfinished lessons as assignments. MANOVA results revealed no significant difference in the teaching practices based on educational qualifications.

\section{Conclusion}

Teachers regularly apply intellectually-related, physically-related, and emotionally-related practices in their online classes. Moreover, teachers employ to a greater extent emotionally-related practices as they manifest positive attitude toward their students, create coping toolbox, give student venue to release their feelings, practice gentleness in giving reminders or corrections, listen with a heart, become generous with praises, mindful of the learner's feelings and responses, and crack jokes and uses humor. These teaching practices significantly vary in terms of school especially with the use of interactive applications, encouragement to do physical exercises, and cracking jokes and humor as big schools which are situated in the city proper are equipped with technology-ready infrastructures and trainings which may not be available in smaller and remote schools. Teaching practices also significantly differ between age of the teachers and teaching experience. The mixture of younger and older teachers in terms of age and experience vary in their teaching practices in the context of their respective schools. Younger or millennial teachers have teaching practices which may not be similar to that of the older or experienced ones and vice versa.

\section{Recommendations}

Based from the conclusions, the following recommendations may be considered: 1) reinforce the utilization of other teaching practices to create a sense of balance and promote the well-being of students; 2) establish a venue of sharing teaching practices especially in the use of interactive tools, the way students are encouraged to do physical exercises, and the best practice of injecting humor in the class; 3) establish venue of sharing best teaching practices among new and experienced teachers; and 4) conduct further research among the modular-based educators.

\section{References}

Aguilar, K. (2019, September 2). DepEd to issue 'more precise' guidelines on students' homework policy. 
Inquirer.net.https://newsinfo.inquirer.net/1160100/deped-to-issue-more-precise-guidelines-on-studentshomework-policy

Anderson, G. (2020, September 11). Mental Health Needs Rise With Pandemic. Inside Higher Ed. https://www.insidehighered.com/news/2020/09/11/students-great-need-mental-health-support-duringpandemic

Amiel, S. \& Vicent, M. S. (2021, October 3).Lockdown generation: Europe's students in despair as pandemic lingers. Euronews. https://www.euronews.com/2021/03/10/lockdown-generation-europe -s-students-indespair-as-pandemic-lingers

Ayo, E., Montero, D., Dote, D., Villanueva, L. \& Verano, C. (2020). Development of Online Teachers-Student Consultation Application. International Association of Online Engineering. Retrieved July 28, 2021 from https://www.learntechlib.org/p/216965/

Blaine, A. (2019). Interaction and presence in the virtual classroom: An analysis of the perceptions of students and teachers in online and blended. Advanced Placement courses. https://doi.org/10.1016/j.compedu.2019.01.004

Cansoy, R.(2019). The Relationship between School Principals' Leadership Behaviours and Teachers' Job Satisfaction: A Systematic Review. International Education Studies. V12, n1, pp37-52. https://files.eric.ed.gov/fulltext/EJ1201517.pdf

Center for Disease Control and Prevention [CDC]. (2020). Coronavirus disease 2019 (COVID-19): Stress \& coping. https:/www.cdc.gov/coronavirus/2019-ncov/daily-life-coping/managing-stress-anxiety.html

Chiu, C.-J., Tasi, W.-C., Yang, W.-L., \& Guo, J.-L. (2019). How to help older adults learn new technology? Results from a multiple case research interviewing the internet technology instructors at the senior learning center.Comput. https://www.sciencedirect.com/science/article/abs/pii/S0360131518302914

Creech, A. (2019). Using Music Technology Creatively to Enrich Later-Life: A Literature Review. Frontiers in Psychology, 117.DOI: 10.20429/cimle.2021.250210

Elsalem, L., Al-Azzam, N., Jum'ah, A. A., Obeidat, N., Sindiani, A. M., \& Kheirallah, K. A. (2020). Stress and behavioral changes with remote E-exams during the Covid-19 pandemic: A cross-sectional study among undergraduates of medical sciences. Annals of Medicine and Surgery, 60, 271-279.

Fernández-Batanero, J. M., Román-Graván, P., Reyes-Rebollo, M. M., \& Montenegro-Rueda, M. (2021). Impact of educational technology on teacher stress and anxiety: A literature review. International Journal of Environmental Research and Public Health, 18(2), 548.

Holmes, T. H., \& Rahe, R. H. (1967). The social readjustment rating scale. Journal of psychosomatic research.

Howell, Penny B.; Gnau, Alice; Peavley, Laura; and Workman, Caitlyn (2020) "Field Experiences in the Ether: The Pandemic-induced Realities of Learning to Teach," Current Issues in Middle Level Education: Vol. 25 :Iss. 2 , Article 10.

Irawan, A.W., Dwisona, D., \& Lestari, M. (2020). Psychological Impacts of Students on Online Learning During the Pandemic COVID-19. https://doi.org/10.24042/kons.v7i1.6389

Justice, Education Departments Issue Fact Sheet on Supporting Students at Risk of Self Harm during COVID-19 Era. (2021, October 13). U.S. Department of Justice. https://www.justice.gov/opa/pr/justice-educationdepartments-issue-fact-sheet-supporting-students-risk-self-harm-during

Kang, N. H., \& Seo, J. (2021). Emerging Online Science Teaching Practices: Insights from High School Physics Teaching Cases in South Korea during COVID-19 Pandemic. Asia-Pacific Science Education, 7(2), 343-383.

Kaloeti, D. V. S. \&Manalu, R. (2021). Because the sky is the limit: Interpretive phenomenological analysis of millennial elementary school teachers using digital technology in the classroom. Premiere Educandum: JurnalPendidikanDasardanPembelajaran, 11(1), 58 - 74. doi.org/10.25273/pe.v11i1.7843

Kini T. \&Podolsky, A. (2019). Does Teaching Experience Increase Teacher Effectiveness? A Review of the Research..https://learningpolicyinstitute.org/product/does-teaching-experience-increase-teachereffectiveness-review-research

Lazarus, R. S. (1966). Psychological stress and the coping process. New York, NY: McGraw-Hill.

Lazarus, R. S., \& Folkman, S. (1984). Stress, appraisal, and coping. New York, NY: Springer.

Luistro, A. A. (2010, September 7). Guidelines on giving homework or assignments to all public school elementary pupils. [Memorandum]. Department of Education. https://www.deped.gov.ph/wpcontent/uploads/2018/10/DM_s2010_392.pdf

Marcén-Román, Y., Gasch-Gallen, A., Vela Martín de la Mota, I. I., Calatayud, E., Gómez-Soria, I., \& RodríguezRoca, B. (2021). Stress Perceived by University Health Sciences Students, 1 Year after COVID-19 Pandemic. International Journal of Environmental Research and Public Health, 18(10), 5233.

Moorhouse, B. L., \& Wong, K. M. (2021). The COVID-19 Pandemic as a catalyst for teacher pedagogical and technological innovation and development: Teachers' perspectives. Asia Pacific Journal of Education, 1-16.

Onwuegbuzie, A. J., \& Collins, K. M. (2007). A typology of mixed methods sampling designs in social science 
research. Qualitative Report, 12(2), 281-316.

Redinger, J. W., Cornia, P. B., \& Albert, T. J. (2020). Teaching during a pandemic. Journal of Graduate Medical Education, 12(4), 403-405.

Rotas, E., \& Cahapay, M. (2021). From stress to success: Exploring how Filipino students cope with remote learning amid COVID-19 pandemic. Journal of Pedagogical Sociology and Psychology, 3(1), 27-35.

Tartavulea, C. V., Albu, C. N., Albu, N., Dieaconescu, R. I., \& Petre, S. (2020). Online Teaching Practices and the Effectiveness of the Educational Process in the Wake of the COVID-19 Pandemic. Amfiteatru Economic, 22(55), 920-936.

Toquero, C. M. D. (2020). Emergency remote teaching amid COVID-19: The turning point. Asian Journal of Distance Education, 15(1), 185-188.

Zhang, X., Wong, J.L.N., \& Wang, X. (2021). How do the leadership strategies of middle leaders affect teachers' learning in schools? A case study from China, Professional Development in Education. https://www.researchgate.net/publication/350885991_How_do_the_leadership_strategies_of_middle_leade rs affect teachers' learning in schools_A case study from_China

Zhang, C., Yan, X., \& Wang, J. (2021). EFL Teachers' Online Assessment Practices During the COVID-19 Pandemic: Changes and Mediating Factors. The Asia-Pacific Education Researcher, 1-9. 